\title{
Study of morphological characters of pollen grains sweet chestnut (Castanea sativa Mill.) by scanning electron microscopy
}

\author{
Vladimíra Horčinová Sedláčková1*, Olga Grygorieva², Ivan Gurnenko² \\ ${ }^{1}$ Slovak University of Agriculture in Nitra, Faculty of Agrobiology and Food Resources, \\ Institute of Biodiversity Conservation and Biosafety, Nitra, Slovakia \\ ${ }^{2}$ M.M. Gryshko National Botanical Garden of Ukraine, National Academy of Sciences, Kyiv, Ukraine
}

Article Details:

Received: $\quad$ 2021-03-19

Accepted: $\quad 2021-04-12$

Available online: 2021-05-31

\begin{abstract}
The studying of Castanea sativa Mill. pollen allows us to determine the details of morphological characteristics and described the most important parameters and pollen sculpture that can be used to identify representatives of species. The general characteristics and significant morphological traits of pollen grains of 16 genotypes Castanea sativa Mill. collected from M.M. Gryshko National Botanical Garden of Ukraine(Kyiv) were observed via a scanning electron microscope (SEM). The measurement of morphometric parameters was carried out on 50 pollen grains from each genotype using the AxioVision Rel. 4.8.2.0 program. The length of the polar axis (P) and the equatorial diameter (E) of grain, $\mathrm{P} / \mathrm{E}$ ratio were measured and their variation was compared among studied genotypes. SEM investigations showed that the pollen grains of Castanea sativa are small-sized, the equatorial view is elliptic, the polar view is angular, with convex mesocolpia, more or less circular. This study showed the small differences between the genotypes in all measured factors. The average polar axis and equatorial diameter of pollen grains values varied in the interval 19.10 $\pm 0.21-20.53 \pm 0.21$ and $8.86 \pm 0.05-9.85 \pm 0.08$, respectively. We determined the variation coefficient in the range of 3.37-8.93\%. It was noted that diversity of surface sculpturing of pollen grains in combination with shape and sizes enables to use of a complex of thin morphological signs for Castanea sativa pollen identifications.
\end{abstract}

Keywords: Castanea sativa, genotype, pollen, SEM, morphology

\section{Introduction}

Castanea sativa Mill. (Fagaceae Dumort.) is a species of chestnut native grown in South-Eastern Europe and Asia Minor. Sweet chestnut (Castanea sativa Mill.) is a multipurpose species that is cultivated for its nuts and contributes positively to the forestry landscape. It is distributed mainly in the Northern Hemisphere, in Asia mostly in China, Korea and Japan, in Southern Europe from Turkey to the Atlantic Islands and in the United States. Southern Europe and Turkey is the main area where Castanea sativa is predominant (Silici et al., 2007).

Flowering chestnuts occurs over a relatively wide period, depending on climatic conditions, especially temperature. The opening of male flowers and the release of pollen occurs from mid-June in early flowering forms, until mid-July in late flowering forms. However, the successively flowering of male flowers can also be observed within the tree at various levels. At the level of the shoot, first, the male catkins bloom at the base and later the catkins closer to the top and finally the male part of the bisexual catkins. At the level of the catkin, the flowers in the lower part bloom first and later the flowers in the upper part of the catkin. At the level of the glomerulus, flowers bloom at the perimeter and then in the centre of the glomerulus. Pollen from bisexual catkins is released at a time when unisexual catkins have already bloomed. This pollen has the same viability as pollen from unisexual catkins and the ability to fertilize female flowers. Pollen releases from the end of August to the beginning

\footnotetext{
*Corresponding Author: Vladimíra Horčinová Sedláčková, Slovak University of Agriculture in Nitra, Faculty of Agrobiology and Food Resources, Institute of Biodiversity Conservation and Biosafety, Nitra, Slovakia $\triangle$ vladimira.sedlackova@uniag.sk
} 
of September from the secondary catkins forming on summer shoots. The formation of summer shoots can be caused by an unusual course of weather during vegetation, but it can also be a permanent feature of some genotypes (Benčat', 1967; Bolvanský et al., 2008; Bakay and Pástor, 2015).

Pollen grains adapted to different strategies of pollination and also have anatomical-morphological differences. These male haploid organisms usually have variable parameters: the pollen shape and size, the number, type, and position of apertures, and the pollen wall with its diverse structure and sculpture. The characters of these parameters in comparative pollen (and spore) morphology are at least as important as any other morphological character of the diploid generation (Halbritter et al., 2018).

Pollen morphological studiesproved to beindispensable for the understanding of evolutionary processes and systematics (Persson et al., 1996; Carlo and Paula, 2004).The ability to identify plants from their pollen has enabled botanists and ecologists to reconstruct past assemblages of plants and identify periods of environmental change (e.g., Fægri and Iversen, 1989; Moore et al., 1991). Research into the morphological characteristics of pollen grains by scanning electron microscopy (SEM) of specific genotypes and cultivars are important and useful for taxonomy, palaeobotany, phylogeny, breeding programmes, e.g. (Giveyrel et al., 2000; Radice et al., 2003).

Taxonomists and paleobotanists considered the importance of pollen development and morphology in clarifying the classification and identity of many plant species, e.g., Cornus mas L. (Mert, 2009), Crataegus spp. (Wrońska-Pilarek et al., 2013), Diospyros virginiana L. (Grygorieva et al., 2017), Pyrus communis L. (Motyleva et al., 2017), Sambucus nigra L. (Horčinová Sedláčková et al., 2020; Wrońska-Pilarek et al., 2020), Aronia mitschurinii A.K. Skvortsov \& Maitul. (Grygorieva et al., 2018), Prunus persica (L.) Batsch (Radice et al., 2003), Malus domestica Borkh (Motyleva et al., 2017, 2018), Rubus fruticosus L. (Motyleva et al., 2018).

Data about Fagaceae pollen morphology were obtained due to the use of a light microscope (LM) and scanning electron microscope (SEM) by authors Bergamini (1975) in Italy, Solignat and Chapa (1975) in France, Mert et al. (2007), Tüylü and Sorkun (2007), Evrenosoglu and Misirli (2009) and Çelemli et al. (2016) in Turkey, Grygorieva et al. $(2015,2016)$ in Slovakia and Ukraine. The complex of morphological characteristics and ultrastructure allows determining the differences (or similarities) between the Castanea species (van Benthem et al., 1984; Grygorieva et al., 2015; Xioung et al., 2020).

The knowledge of pollen morphological characteristics can be an adequate method for identification genotypes of Castanea sativa.

\section{Material and methodology}

\section{Locating trees and data collection}

The pollen of 16 Castanea sativa genotypes (CS-01 CS-16) from the collection of M.M. Gryshko National Botanical Garden of NAS of Ukraine (NBG) was investigated at the laboratory of the Department of Tropical and Subtropical plants of NBG. Collected pollen from 30-year-old Castanea sativa plants (Figure 1).

\section{Pollen grains collection}

Freshly flowers (not opened) were collected randomly from the different genotypes at the balloon stage (June 2020). Pollen samples released from male flowers (catkins) were further dried under laboratory conditions. The dry pollen was used for a microscopic study of morphological characteristics. The samples of pollen grains were applied to double-tape, fastened to metal object tables with $10 \mathrm{~mm}$ diameter.

\section{Scanning electron microscopy (SEM)}

The pollen grains were studied at the laboratory of the Department of Tropical and Subtropical plants of NBG using an electron microscope Carl Zeiss LS 15, and the microphotographs were taken. The comparative morphological studying of the pollen grains was performed according to the working rules on the SEM JEOL JSM-6390 in the conditions of low vacuum $(\mathrm{P}=60 \mathrm{~Pa})$ with the following zooming: 500 times during the measurements; $1000-10000$ times - while taking the pictures of the exine sculpture features. Using the regime of low vacuum allows performing the pollen studying without its preliminary chemical treatment and to receive undistorted data about the research object that makes the process of the probe preparation easier. Typical exine patterns, shape, sizes and dimensions of pollen grains for Castanea sativa individuals were determined by using a scanning electron microscope (SEM).

\section{Morphometric characteristics}

The measurement of morphometric parameters was carried out on 50 pollen grains from each genotype using the AxioVision Rel. 4.8.2.0 program. The measurements were made in micrometres $(\mu \mathrm{m})$. The 


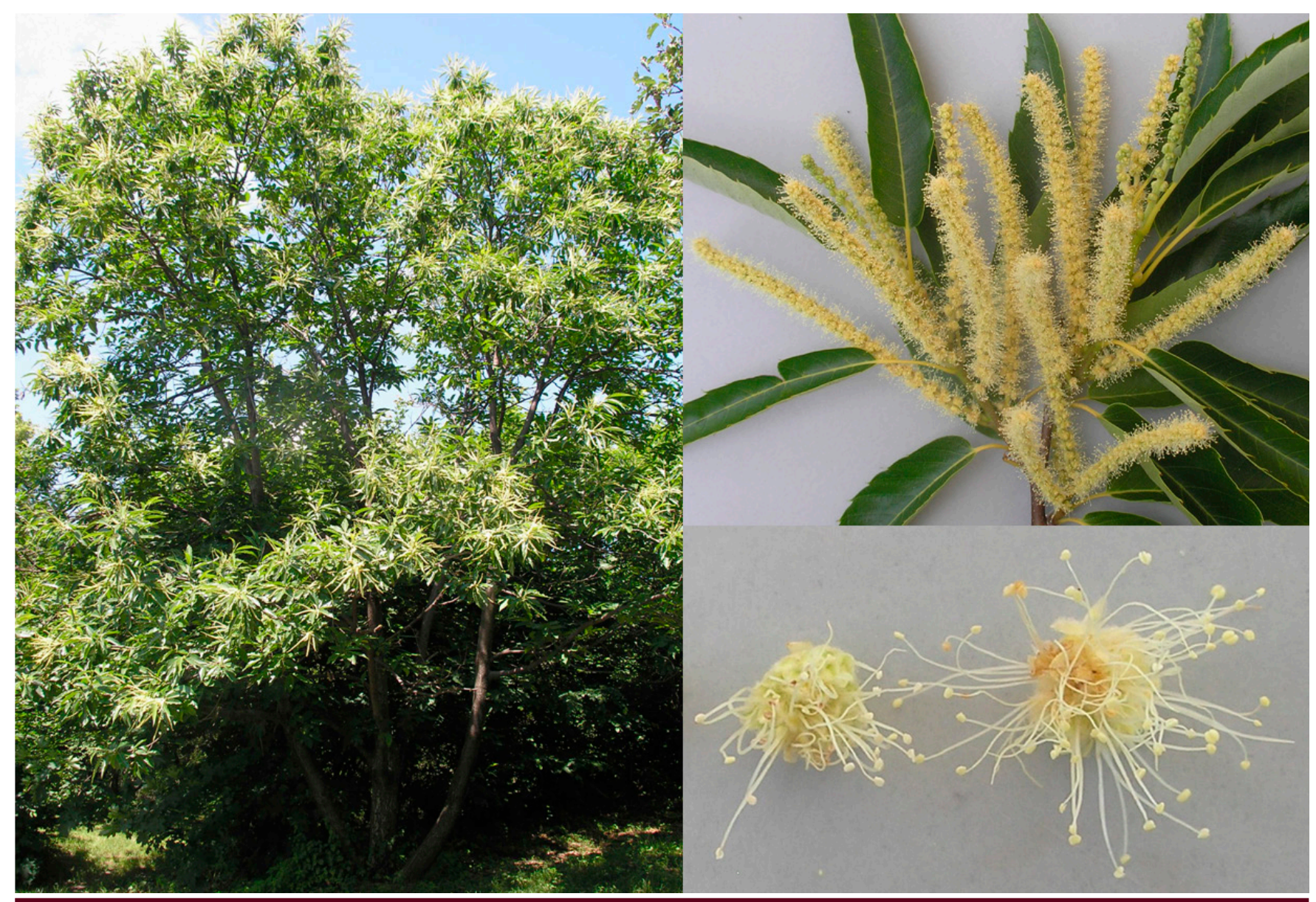

Figure 1 Castanea sativa Mill. in M.M. Gryshko National Botanical Garden of Ukraine, Kyiv (Photo: Grygorieva, 2019)

characterization of pollen grains was calculated by taking the following parameters: the polar axis (P the line connecting the proximal and distal pole), the equatorial axis ( $\mathrm{E}$ - the line perpendicular to the polar axis and located in the equatorial plane).

\section{Statistical analysis}

Statistical analysis was performed using SAS $\AA_{9.2}$ software; hierarchical cluster analyses of similarity between genotypes were computed on the basis of the Bray-Curtis similarity index; BiPlot analysis was performed in SAS ${ }^{\circledR} 9.2$ software. The variability of all these parameters was evaluated using descriptive statistics. Level of variability determined by Stehlíková (1998).

\section{Results and discussion}

A study of 16 evaluated individuals of Castanea sativa pollen morphology showed that pollen grains are very small-sized. Using optical microscopy the pollen grain of Castanea sativa type is 3-zonocolporate, isopolar, $\mathrm{P} / \mathrm{E}$ ratio is prolate, outline in the polar view is lobate, the grain is 3 apertures. Ectoaperture is colpus, long, narrow and sunken; margins are distinct, regular; ends acute; colpus membrane occasionally with irregular granules; fastigium absent; sexine extensions above endoaperture usually present; costae colpi absent. Endoaperture is colpus, lalongate, elliptic in outline; margins are distinct, straight; ends acute or irregularly diffuse, sometimes with horns; costae distinct, narrow. Exine is thin. Sexine equally thick, or slightly thicker than nexine. Sexine subdivisions weakly developed. Outlines: Equatorial view is elliptic, the polar view is angular, with convex mesocolpia, more or less circular. Ornamentation under the scanning electron microscope is rugulate, perforate, tectum is eutectate, infratectum columellate, columellae is very short, endexine is compact-continuous, intine monolayered, pollen coatings absent, Ubisch bodies are present. We can confirm theis knowledge with some authors (van Benthem et al., 1984; Mert et al., 2007; Grygorieva et al., 2015, 2016; Çelemli et al., 2016; PalDat, 2021).

This type is easily distinguished from other types in the Fagaceae family by its much smaller size, its endocolpus and its semi-erect to erect $\mathrm{P} / \mathrm{E}$ ratio. 


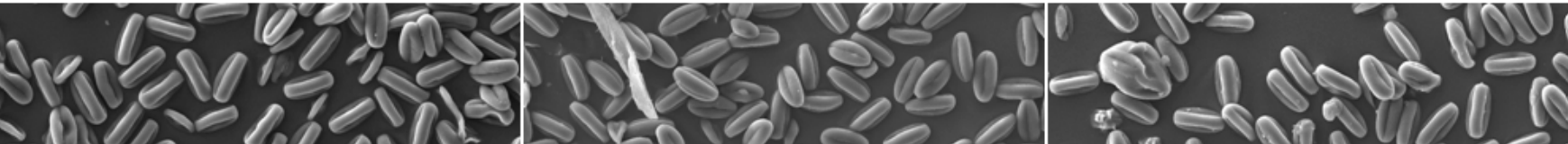

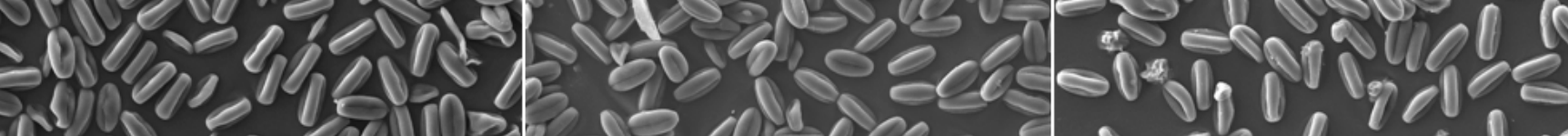

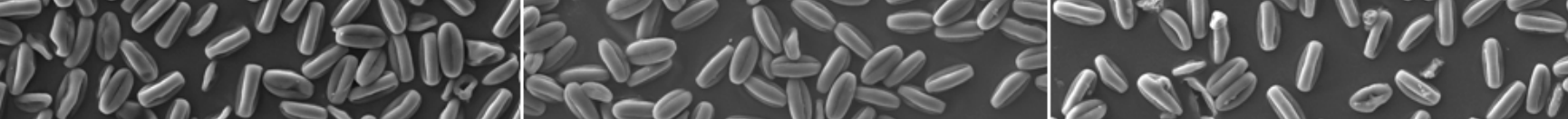
G Wos a

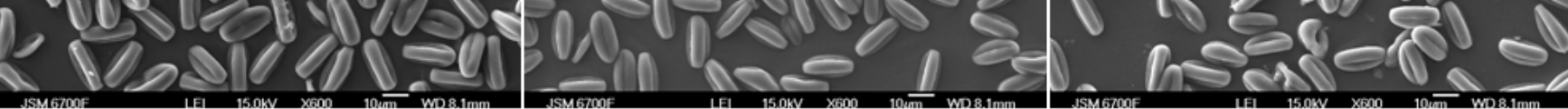

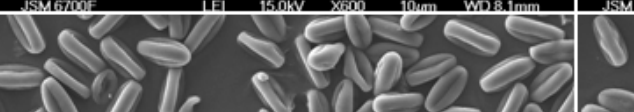

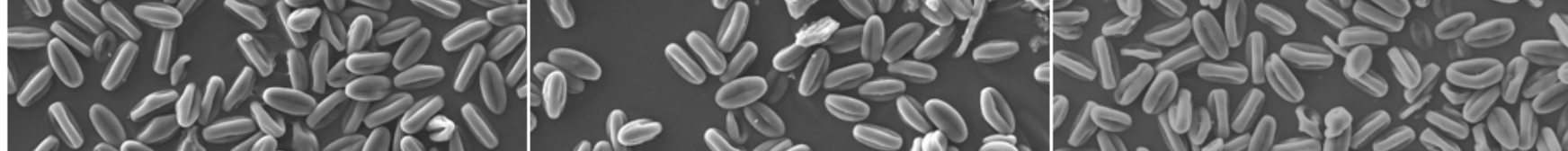

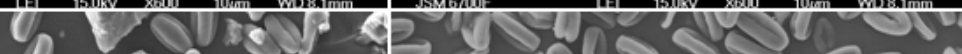

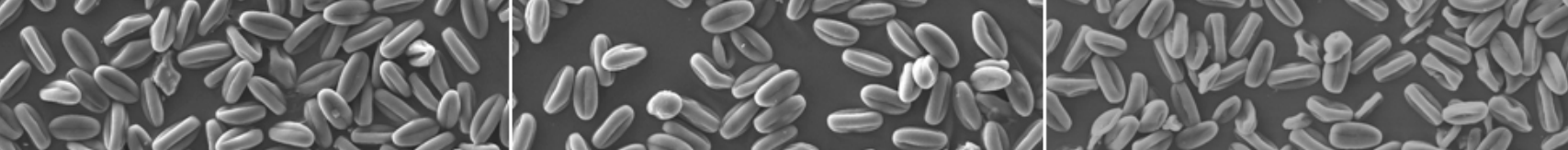

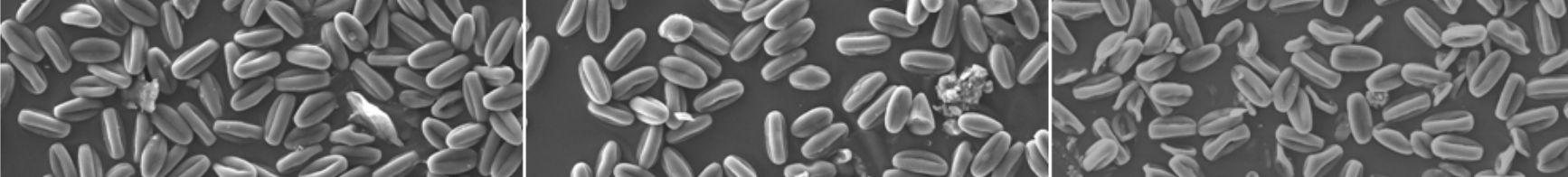
ISMGroof

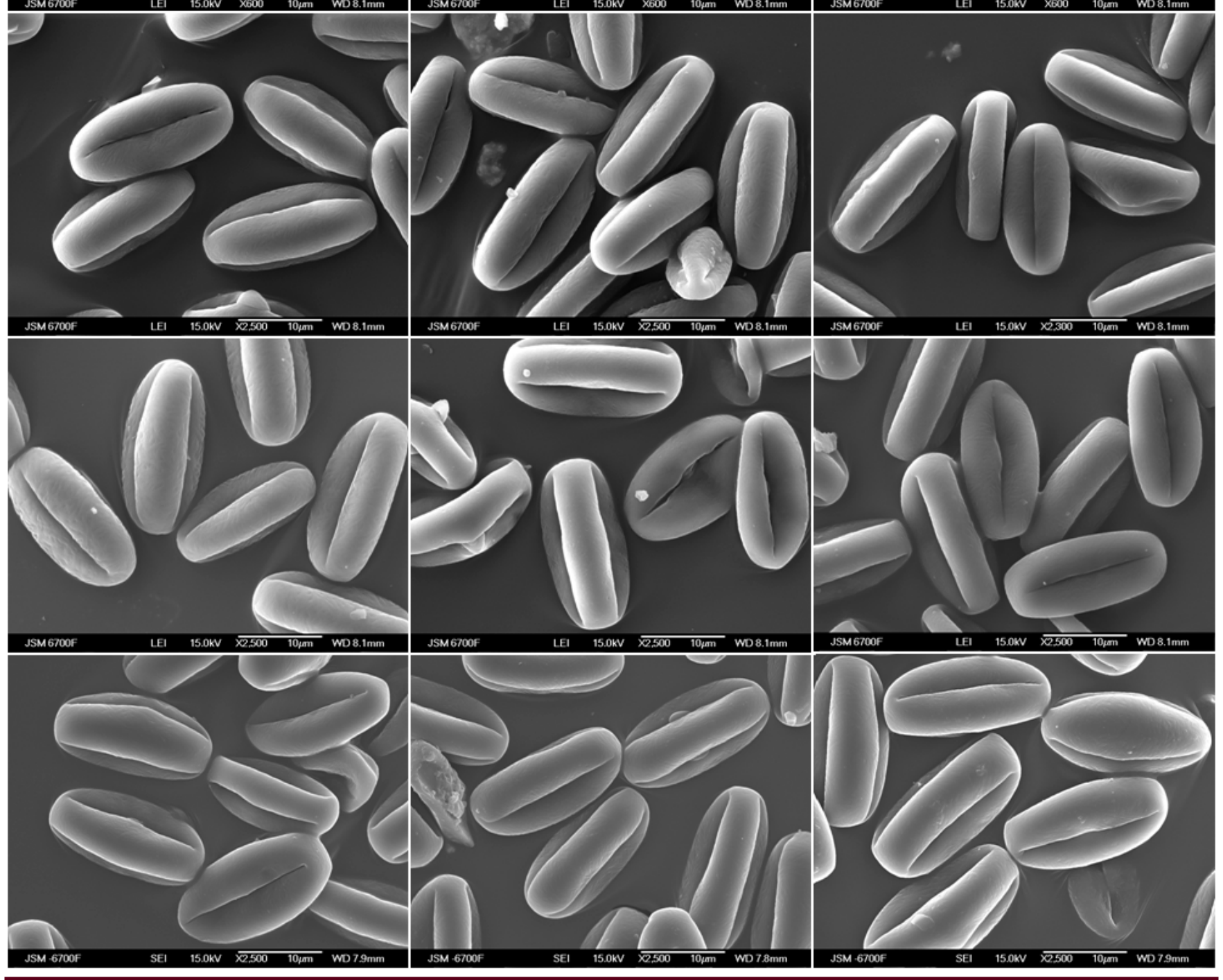

Figure 2 Pollen grains of Castanea sativa Mill. species in different positions (Photo: Gurnenko, 2020) 
Furthermore, this type differs in the thickness of the exine and the rather smooth appearance of the grains in LM, in contrast with the sculptured grains of the Fagus and Quercus types. Its endocolpus, especially at the ends, is less regular than the endoaperture of Fagus sylvatica (van Benthem et al., 1984).

The polar axis (P), equatorial diameter (E) and polar axis to equatorial diameter $(\mathrm{P} / \mathrm{E})$ ratio of pollen grains of sixteen Castanea sativa individuals were measured using scanning electron microscopy (SEM), and the results are displayed in Table 1 . An important morphological trait is the size of pollen grains. The length of the polar axis (P) varied from 13.13 (CS-14) to 23.75 (CS-16) $\mu \mathrm{m}$ and the width of the equatorial axis (E) was in the range from 6.57 (CS-14) to 11.84 (CS-10) $\mu \mathrm{m}$. The average length of the polar axis was in the interval $19.10 \pm 0.21$ (CS-04, CS-15) - $20.53 \pm 0.21$ (CS-14), the average width of the equatorial diameter was in the interval $8.86 \pm 0.05$ (CS-08) $-9.85 \pm 0.08$ (CS-10).

According to the average values, the genotype CS-10, CS-12 and CS-14 have the largest pollen grains. The values of variation coefficient were in the range from3.37(CS-102) to 8.93(CS-14) \% for polar axes and from 5.13 (CS-08) to 7.90 (CS-11) \% for equatorial axes. Shape index (SI) of pollen grain depends on parameters of polar (P) and equatorial (E) axis. Shape index (the P/E ratio) of tested species varied from 2.05 (CS-10) to 2.22 (CS-03, CS-08, CS-13). The sizes of pollen Castanea sativa are similar with results of Grygorieva et al. $(2015,2016)$ and Mert et al. (2007), whereas in comparison sizes of pollen grains and P/E ratio (2.05-2.22) with authors Çelemli et al. (2016) (1.37) or Bergaminy (1975) (1.2-1.6) our studied genotypes Castanea sativa are being greater (Table 2).

The obtained results are confirmed by the data of Haragsim (2004), who states that the chestnut belongs to the species with the smallest pollen grains. Solignat and Chapa (1975) determined the pollen length in the interval from 14 to $18 \mu \mathrm{m}$ and a pollen width in the range from 10 to $14 \mu \mathrm{m}$. Modification of length may not be positively correlated with the modification of pollen width. Grygorieva et al. (2015) in their study of evaluation of Ukrainian edible chestnuts reported a pollen length from 12.58 to $24.39 \mu \mathrm{m}$ and width from 7.10 to $13.92 \mu \mathrm{m}$. Thus, the length to width ratio (shape index) can vary from 1.4 to 2.0 , and pollen grains can have a short-elliptical to elongated-elliptical shape.

In the years 2013/2015 Grygorieva et al. (2016) determined and observed the length of pollen grains in the range 17.04-22.65 $\mu \mathrm{m} / 16.78-22.08 \mu \mathrm{m}$ and width

Table 1 The measured pollen morphological traits of selected genotypes of Castanea sativa Mill.

\begin{tabular}{|l||c|c|c|c|c|c|c|c|c|c|c|c|c|c|}
\hline \multirow{2}{*}{ Genotypes } & $\min$ & $\mathbf{m a x}$ & $\mathbf{x}$ & $\mathbf{V} \%$ & $\mathbf{m i n}$ & $\mathbf{m a x}$ & $\mathbf{x}$ & $\mathbf{V} \%$ & $\mathbf{m i n}$ & $\mathbf{m a x}$ & $\mathbf{x}$ & $\mathbf{V} \%$ \\
\cline { 2 - 15 } & \multicolumn{3}{|c|}{$\mathbf{P}-$ polar axis $(\boldsymbol{\mu m})$} & \multicolumn{2}{|c|}{ E- equatorial axis $(\boldsymbol{\mu m})$} & \multicolumn{3}{|c|}{ SI - shape index (P/E) } \\
\hline \hline CS-01 & 17.20 & 20.73 & 19.14 & 4.04 & 8.09 & 10.05 & 9.05 & 5.26 & 1.82 & 2.40 & 2.12 & 6.30 \\
\hline CS-02 & 17.36 & 21.73 & 19.48 & 5.67 & 7.75 & 10.68 & 8.95 & 7.41 & 1.89 & 2.55 & 2.18 & 6.14 \\
\hline CS-03 & 17.13 & 21.53 & 19.78 & 4.60 & 7.20 & 10.65 & 8.94 & 7.12 & 1.91 & 2.56 & 2.22 & 6.47 \\
\hline CS-04 & 16.01 & 21.13 & 19.10 & 7.35 & 7.69 & 10.28 & 9.15 & 5.86 & 1.67 & 2.41 & 2.09 & 8.15 \\
\hline CS-05 & 14.17 & 21.92 & 19.29 & 6.46 & 7.69 & 10.59 & 9.21 & 5.94 & 1.57 & 2.44 & 2.10 & 7.13 \\
\hline CS-06 & 14.44 & 21.65 & 19.51 & 6.07 & 7.04 & 10.28 & 9.03 & 6.12 & 1.83 & 2.59 & 2.16 & 6.81 \\
\hline CS-07 & 17.42 & 20.76 & 19.36 & 4.21 & 8.06 & 10.43 & 9.19 & 6.09 & 1.89 & 2.41 & 2.11 & 5.84 \\
\hline CS-08 & 17.50 & 21.29 & 19.68 & 3.66 & 7.97 & 9.98 & 8.86 & 5.13 & 1.94 & 2.61 & 2.22 & 4.68 \\
\hline CS-09 & 14.38 & 21.74 & 19.70 & 6.09 & 8.50 & 10.99 & 9.46 & 5.77 & 1.62 & 2.43 & 2.09 & 7.86 \\
\hline CS-10 & 18.36 & 21.66 & 20.12 & 3.37 & 8.42 & 11.84 & 9.85 & 6.07 & 1.60 & 2.31 & 2.05 & 6.37 \\
\hline CS-11 & 15.27 & 22.13 & 19.53 & 6.00 & 7.88 & 11.81 & 9.47 & 7.90 & 1.70 & 2.38 & 2.07 & 7.10 \\
\hline CS-12 & 14.31 & 22.67 & 20.16 & 7.07 & 7.94 & 10.50 & 9.33 & 6.25 & 1.76 & 2.41 & 2.17 & 7.90 \\
\hline CS-13 & 16.92 & 22.58 & 19.84 & 5.27 & 7.99 & 10.43 & 8.94 & 5.49 & 1.89 & 2.49 & 2.22 & 5.56 \\
\hline CS-14 & 13.13 & 22.94 & 20.53 & 8.93 & 6.57 & 10.54 & 9.39 & 7.87 & 1.71 & 2.51 & 2.19 & 5.57 \\
\hline CS-15 & 14.07 & 21.12 & 19.10 & 5.82 & 7.40 & 10.28 & 8.98 & 6.43 & 1.84 & 2.41 & 2.13 & 5.90 \\
\hline CS-16 & 16.95 & 23.75 & 19.84 & 5.00 & 7.88 & 10.94 & 9.16 & 5.85 & 1.77 & 2.58 & 2.17 & 7.07 \\
\hline
\end{tabular}

Note: $\min$ - minimum value; max - maximum value; $\mathrm{x}$ - average; $\mathrm{V}$ - variation coefficient $(\%)$ 
Agrobiodivers Improv Nutr Health Life Qual, 5, 2021(1): 116-125

Table 2 Literature data on pollen morphological traits in the Castanea sativa Mill.

\begin{tabular}{|c|c|c|c|}
\hline Characteristic & Value & Authors & Country \\
\hline \multirow{8}{*}{ Polar axis $(\mu \mathrm{m})$} & $10-15$ & Bergaminy, 1975 & Italy \\
\hline & $14-18$ & Solignat\&Chapa, 1975 & France \\
\hline & $13.33-21.30$ & Mert et al., 2007 & Turkey \\
\hline & 14.48 & Tüylü\&Sorkun, 2007 & Turkey \\
\hline & $16.25(11.3-18.3)$ & Evrenosoglu \& Misirli, 2009 & Turkey \\
\hline & $12.58-24.39$ & Grygorieva et al., 2015 & Ukraine \\
\hline & $16.78-22.65$ & Grygorieva et al., 2016 & Slovakia \\
\hline & $12-16$ & Çelemli et al., 2016 & Turkey \\
\hline \multirow{8}{*}{ Equatorial axis $(\mu \mathrm{m})$} & $8-12$ & Bergaminy, 1975 & Italy \\
\hline & $10-14$ & Solignat \& Chapa, 1975 & France \\
\hline & - & Mert et al., 2007 & Turkey \\
\hline & 12.46 & Tüylü\&Sorkun, 2007 & Turkey \\
\hline & $8.15(6.5-9.2)$ & Evrenosoglu \& Misirli, 2009 & Turkey \\
\hline & $7.10-13.92$ & Grygorieva et al., 2015 & Ukraine \\
\hline & $7.21-12.07$ & Grygorieva et al., 2016 & Slovakia \\
\hline & $10-13$ & Çelemli et al., 2016 & Turkey \\
\hline \multirow{8}{*}{ SI - shape index } & $1.2-1.6$ & Bergaminy, 1975 & Italy \\
\hline & - & Solignat \& Chapa, 1975 & France \\
\hline & - & Mert et al., 2007 & Turkey \\
\hline & 1.16 & Tüylü \& Sorkun, 2007 & Turkey \\
\hline & $2.02(1.75-2.27)$ & Evrenosoglu \& Misirli, 2009 & Turkey \\
\hline & $1.4-2.0$ & Grygorieva et al., 2015 & Ukraine \\
\hline & - & Grygorieva et al., 2016 & Slovakia \\
\hline & 1.37 & Çelemli et al., 2016 & Turkey \\
\hline
\end{tabular}

of pollen grains in the range 7.21-12.07 $\mu \mathrm{m} / 7.32-$ $11.22 \mu \mathrm{m}$ in the conditions of Slovakia. Bergamini (1975) detected for various staminal types a pollen length of $10-15 \mu \mathrm{m}$, pollen width of $8-12 \mu \mathrm{m}$ and a shape index of 1.2-1.6. It has been found that the size of the pollen grains, expressed by the length of their polar axis, is positively correlated with the length of the stamens. Individuals of the brachystaminate type have smaller pollen grains than individuals of the mesostaminate type and those, in turn, smaller grains than individuals of the longistaminate type. However, variability in the size and shape of pollen grains also occurs within an individual genotype (Bolvanský and Salaj, 1988).

In our work, we confirmed that pollen grains have a short-elliptical to elongated-elliptical shape, which is documented in Figures 1.

Mert et al. (2007) described pollen grains of both male-fertile ('Firdola', 'Karamehmet', 'Sarialama', and 'Haciomer') and male-sterile ('Osmanoglu' and 'VakitKestanesi') chestnut (Castanea sativa Mill.) cultivars like tricolporate, the germinal furrow extending almost the full length of the grain axis. Pollen grains have a slightly reticulate exine. Pollen grain length varied from 13.33-21.30 $\mu \mathrm{m}$ and decreased significantly in the male-sterile cultivars. Three different pollen shapes were observed among the cultivars: prolate, perprolate, and sub-prolate. The ultrastructure of the pollen grains did not differ between male-fertile and male-sterile cultivars. Intine, exine and total wall thickness (exine + intine) of pollen grains were determined as $83.2-153.1 \mathrm{~nm}$, $432.8-520.0 \mathrm{~nm}$, and 516.0-651.6 nm, respectively; and variations were significant $(p<0.05)$ among cultivars.

Based on the cluster analysis of all 16 studied pollen characteristics, a dendrogram for the genotypes of Castanea sativa was made (Figure 3). On the 


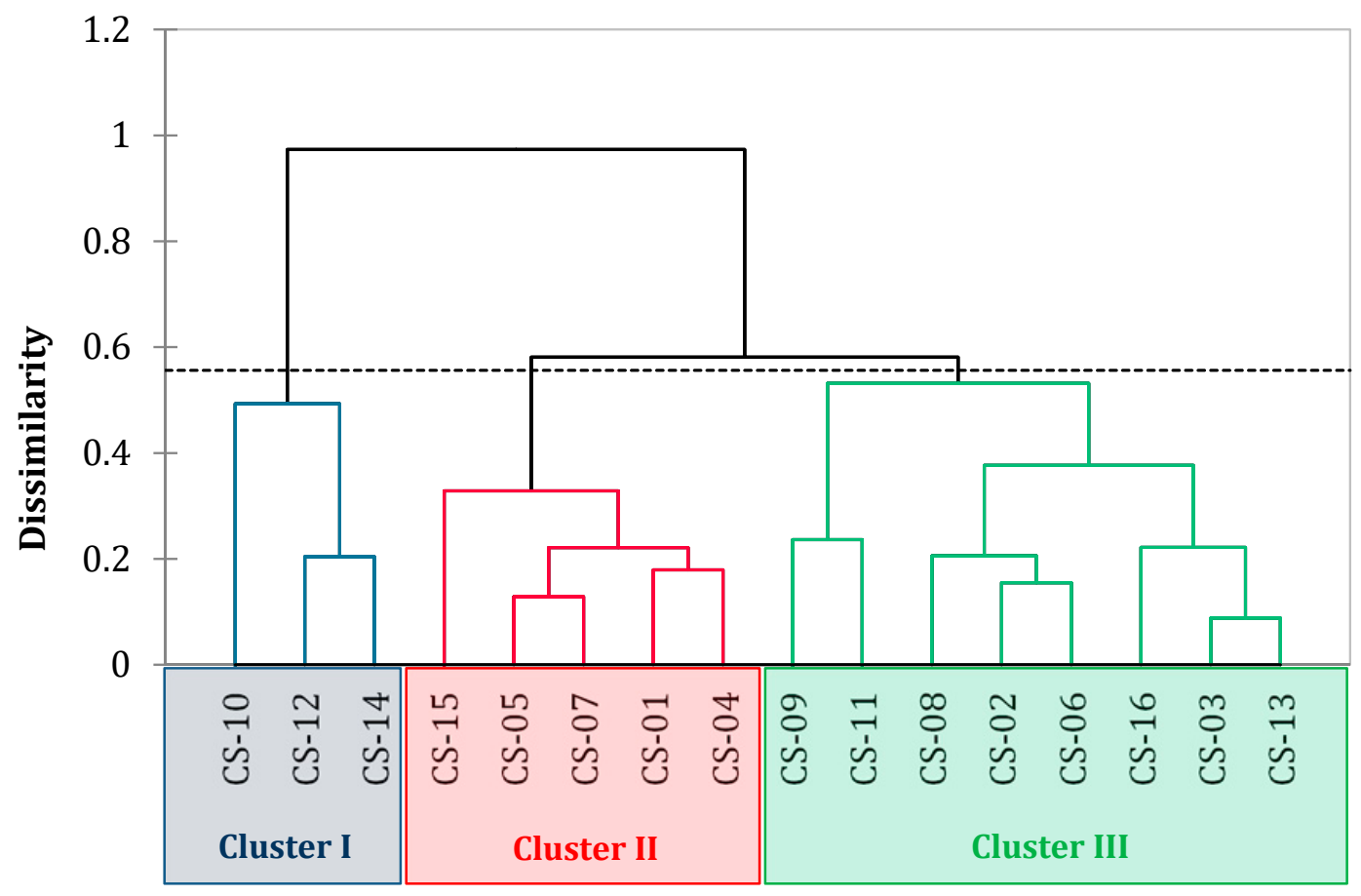

Figure 3 Cluster dendrogram of morphometric parameters pollen of Castanea sativa Mill. genotypes

dendrogram, you can see three main clusters, while cluster I (CS-10, CS-12, CS-14) has the highest values, cluster II (CS-01, CS-04, CS-05, CS-07 and CS-15) has the lowest values.

More detailed relationships between genotypes were revealed by Principal component analysis (PCA). The PCA used in our work showed that $99.98 \%$ of the variability observed was explained by the first two components (Table 3). PC1, PC2, and PC3 accounted for $55.77,44.21$ and $0.02 \%$, respectively. PC1 was positively correlated with the polar and equatorial axis, whereas the shape index showed a low negative correlation. PC2 was positively correlated with the polar and equatorial axis and shape index. Positive values for PC1 correspond to the genotypes with a higher polar axis as shown in Figure 4. Genotypes CS-10, CS-12 and CS-14 were included in this group.

The highest negative values for PC1 indicate the genotypes with the smallest polar axis. This group includes genotypes CS-01and CS-15 (Figure 4). The genotypes CS-03 and CS-13 have the highest PC2 due to the highest equatorial axis. The positive PC3 value indicates the largest shape index. These characteristics were observed in genotypesCS-03, CS-08, CS-13.

Table 3 Eigenvalues and proportion of total variability, eigenvectors of the three principal components (PC), and component scores for Castanea sativa Mill. pollen 16 genotypes

\begin{tabular}{|c|c|c|c|}
\hline \multirow[t]{2}{*}{ Selection } & \multicolumn{3}{|c|}{ Component scores } \\
\hline & PC1 & PC2 & PC3 \\
\hline Eigenvalue & 1. 673 & 1. 326 & 0.001 \\
\hline Variance (\%) & 55.77 & 44.20 & 0.024 \\
\hline Cumulative & 55.77 & 99.98 & 100.000 \\
\hline \multirow[t]{2}{*}{ Variable } & \multicolumn{3}{|c|}{ Component loadings } \\
\hline & PC1, $\lambda=55.77$ & $\mathrm{PC} 2, \lambda=44.20$ & PC3, $\lambda=0.02$ \\
\hline Polar axis $(\mu \mathrm{m})$ & 0.167 & 0.848 & -0.503 \\
\hline Equatorial axis $(\mu \mathrm{m})$ & 0.747 & 0.225 & 0.625 \\
\hline SI - shape index & -0.644 & 0.481 & 0.595 \\
\hline
\end{tabular}


Biplot (PC1 and PC2: $99.98 \%)$

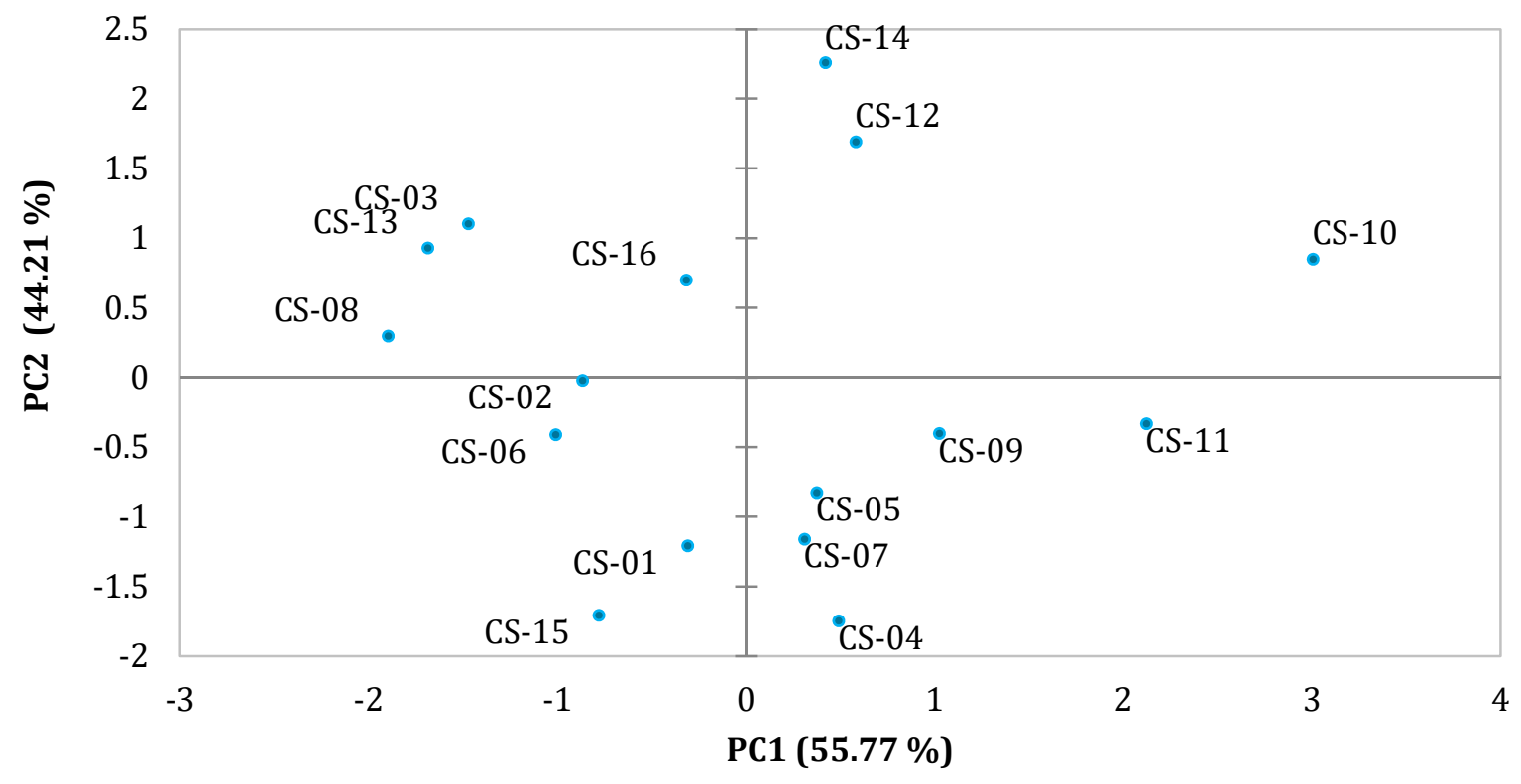

Figure 4 Biplot based on principal components analysis (PCA) for pollen morphometric parameters of Castanea sativa Mill. 16 genotypes

\section{Conclusions}

The studying of the Castanea sativa pollen via scanning electron microscope allowed us to determine the most important parameters which can be used to identify the representatives of species. The detailed pollen morphological and micro-sculptural characteristics were investigated, described and analyzed by using hierarchical cluster analysis dendrogram and BiPlot. The main parameters such as the form (the pollen grains elongation, the length and the width ratio) are specific for different Castanea species. Results from our analyses showed small differences among Castanea sativa phenotypes from Ukraine. Some of these pollen morphological parameters can be used for identification and comparison with the following analyses of Castanea species phenotypes.

\section{Acknowledgements}

The publication was prepared with the active participation of researchers involved in the International network AgroBioNet of the Institutions and researchers for the realization of research, education and development program «Agrobiodiversity for improving nutrition, health and life quality» and within the project ITEBIO - ITMS 26220220115. This study was supported by SAIA for the scholarship grants for the research stay during which the presented knowledge was obtained.

\section{References}

BAKAY, L. and PÁSTOR, M. 2015. Comparison of catkins length of European chestnut (Castanea sativa Mill.) at the localities of Modrý Kameň, Plachtince and Príbelce. In Conference: Trendy v krajinotvorbe : Nitra, vol. 2.

BENČǍ̆, F. 1967. Typy súkvetí Castanea sativa Mill. [Inflorescences types of Castanea sativa Mill.]. In Roczn. Sekc. Dendrol. Polsk. Tow. Bot., č. 21, s. 191-202. [In Slovak].

BERGAMINI, A. 1975. Ossevazioni sul lamorfologiafiorale di alcune cultivar di castagno. In Riv. Ortoflorofrut, 59, p. 103-108.

BOLVANSKÝ, M. and SALAJ, J. 1988. Vel'kost' a tvar pel'ových zŕn pri rôznych tyčinkových typoch gaštana jedlého (Castanea sativa Mill.) [Size and shape of pollen grains for different staminal types of sweet chestnut (Castanea sativa Mill.)]. In Biológia, roč. 43, č. 1, s. 11-12. [In Slovak].

BOLVANSKÝ, M., BRINDZA, J., MENDEL, L., UŽÍK, M. 2008. Gaštanjedlý (Castanea sativa Mill.): biológia, pestovanie a využívanie [Sweet chestnut (Castanea sativa Mill.): Biology, Cultivation and Using]. Nitra : SPU. ISBN 97880-552-0076-7. [In Slovak].

CARLO, D. and PAULA, R. 2004. New insights into pollen evolution. In International Journal of Plant Sciences, vol. 164, p. 835.

ÇELEMLI, Ö. G., TEMIZER, İ. K., ZARE, G., SORKUN, K. 2016. Castanea sativa; a source of Turkish propolis: plant anatomy, palynology and chemistry. In Hacettepe J. Biol. \& Chem., vol. 44 (1), p. 7-14. https://doi.org/10.15671/HJBC.20164417560 
EVRENOSOĞLU, Y., MISIRLI, A. 2009. Investigations on the pollen morphology of some fruit species. In Turk. J. Agric. For., vol. 33(2), p. 181-190.

https://doi.org/10.3906/tar-0801-47

FÆGRI, K., and IVERSEN, J. 1989. Textbook of pollen analysis. $4^{\text {th }}$ ed. John Wiley and Sons, Chirchester.

GIVEYREL, L., LE THOMAS, A., FERGUSON, K., CHASE, M.W. 2000. Critical reexamination of palynological characters used to delimit Asclepidaceae in comparison to the molecular phylogeny obtained from plastid mark sequences. In Molecular Phylogenetics and Evolution, vol. 9, p. 517-527.

GRYGORIEVA, O., KLYMENKO, S., VINOGRADOVA, Y., MOTYLEVA, S., GURNENKO, I., PIÓRECKI, N., BRINDZA, J. 2018. Study of morphological characteristics of pollen grains of Aronia mitschurinii A.K. Skvortsov \& Maitul. In Agrobiodiversity for Improving Nutrition, Health and Life Quality, vol. 2, p. 49-56.. https://doi.org/10.15414/ agrobiodiversity.2018.2585-8246.049-056

GRYGORIEVA, O., MOTULEVA, S., NIKOLAIEVA, N., KLYMENKO, S., SCHUBERTOVÁ, Z., BRINDZA, J. 2017. Pollen grain morphological characteristics of American persimmon (Diospyros virginiana L.). In Agrobiodiversity for Improving Nutrition, Health and Life Quality, vol.1, p. 151-158. http://dx.doi.org/10.15414/ agrobiodiversity.2017.2585-8246.151-15

GRYGORIEVA, O., NIKOLAIEVA, N., BRINDZA, J., KLYMENKO, S. 2015. Pollen and bee pollen features of sweet chestnut (Castanea sativa Mill.). In Scientific Bulletin of the National University of Life and Environmental Sciences of Ukraine. Series: Technology of production and processing of livestock products [online], vol. 223, p. 35-40 http:// journals.nubip.edu.ua/index.php/Tekhnologiya/ article/view/6739/0.

GRYGORIEVA, O., VIČAN, J., SCHUBERTOVÁ, Z., ŠIMKOVÁ, J., ADAMCHUK, L., BRINDZA, J. 2016. morphological characteristics of pollen grains and bee pollen of sweet chestnut (Castanea sativa Mill.). In Agrobiodiversity for Improving Nutrition, Health, and Quality of Life 2016, p. 107-114.

HALBRITTER, H., ULRICH, S., GRIMSSON, F., WEBER, M., ZETTER, R., HESSE, M., BUCHNER, R., SVOJTKA, M., FROSCH-RADIVO, A. 2018. Palynology: History and systematic aspects. Illustrated Pollen Terminology. Springer, Cham.

HARAGSIM, O. 2004. Včelářske dřeviny [Beekeeping trees]. 1. vyd. Praha: Grada Publishing, a. s. 130 s. ISBN 80-2470833-7. [In Czech].

HORČINOVÁ SEDLÁČKOVÁ, V., GRYGORIEVA, O., GURNENKO, I., VERGUN, O. 2020. Diversity of Sambucus nigra pollen within Slovakia in selected morphological caracters by SEM study, In Biosystems Diversity, vol. 28(4), p. 399404. https://doi.org/10.15421/012051

MERT, C. 2009. Pollen morphology and anatomy of cornelian cherry (Cornus mas L.) cultivars. In Horticulture Science, vol. 44(2), p. 519-522.

https://doi.org/10.21273/HORTSCI.44.2.519
MERT, C. and SOYLU, A. 2007. Morphology and anatomy of pollen grains from male-fertile and male-sterile cultivars of chestnut (Castanea sativa Mill.). In Journal of Horticultural Science and Biotechnology, vol. 82 (3), p. 474-480. https://doi.org/10.1080/14620316.2007.11512261

MOORE, P. D., WEBB, J. A., COLLINSON, M. E. 1991. Pollen Analysis. $2^{\text {nd }}$ ed. Blackwell Scientific Publications, Oxford.

MOTYLEVA, S. M., BRINDZA, J., ŠIMKOVÁ, J., HORČINOVÁ SEDLÁČKOVÁ, V. 2018. Comparative study of morphometric characteristics and mineral composition of pollen Malus domestica Borkh. In Agrobiodiversity for Improving Nutrition, Health and Life Quality, vol. 2, p. 285-291. https://doi.org/10.15414/ agrobiodiversity.2018.2585-8246.285-291

MOTYLEVA, S. M., GRUNER, L., SEMENOVA, L. 2018. The Morphology of pollen grains of some cultivars Rubus fruticosus L. In Agrobiodiversity for Improving Nutrition, Health and Life Quality, vol. 2, p. 1-6.

https://doi.org/10.15414/ agrobiodiversity.2018.2585-8246.001-006

MOTYLEVA, S., BRINDZA, J., KULIKOV, I. 2017. The Morphology of pollen grains of the some species of Rosaceae Juss. Family. In Agrobiodiversity for Improving Nutrition, Health and Life Quality, vol. 1, p. 338-341. http://dx.doi.org/10.15414/ agrobiodiversity.2017.2585-8246.338-341

PALDAT. 2021. Palynological Database. [online database]. [cit. 2021-12-03]. https://www.paldat.org/pub/Castanea sativa/303767

PERSSON, V., KANPPS, S., BLACKMORE, S. 1996. Pollen morphology and systematics of tribe Juanulloeae A. T. Hunziker (Solanaceae). In Review of Palaeobotany and Palynology, vol. 83, p. 1-30.

RADICE, S., ONTIVERO, M., GIORDANI, E., BELLINI, E. 2003. Morphology and physiology of pollen grains of Italian Prunus persica (L.) Batsch cultivars grown in Argentina. In Advances in Horticulture and Science, vol. 17(2), p. 93-96.

SILICI, S., ÜNLÜ, M., VARDAR-ÜNLÜ, G. 2007. Antibacterial activityand phytochemical evidence for theplantorigin of Turkish propolis from different regions, In World Journal of Microbiology and Biotechnology, vol. 23, p. 1797-803. https://doi.org/10.1007/s11274-007-9430-7

SOLIGNAT, G. and CHAPA, J. 1975. La biologie florale $d u$ châtaignier. Station de recherches d'Arboricolture Fruitiére. Centre de Recherches de Bordeaux, INRA, $35 \mathrm{~s}$.

STEHLÍKOVÁ, B. 1998. Základy bioštatistiky [Fundamentals of biostatistics]. Učebné texty pre dištančné štúdium. Nitra: Ochrana biodiverzity. [In Slovak].

TÜYLÜ, A.Ö., SORKUN, K.2007.The investigation of morphologic analysis of pollen grains which are economically important and collected by Apis mellifera L. In Hacettepe J. Biol. \& Chem., vol. 35(1), p. 31-38. 
VAN BENTHEM, F., CLARKE, G.C.S., PUNT, W. 1984. The northwest European pollen flora. Fagaceae. Review of Palaeobotany and Palynology. Elsevier Scientific Publishing Company, Amsterdam, 42, p. 87-110.

WROŃSKA-PILAREK, D., BOCIANOWSKI, J., JAGODZIN 'SKI, A.M. 2013. Comparison of pollen grain morphological features of selected species of the genus Crataegus (Rosaceae) and their spontaneous hybrids. In Botanical Journal of the Linnean Society, vol. 172, p. 555-571. https://doi.org/10.1111/boj.12033

WROŃSKA-PILAREK, D., JAGODZIŃSKI, A. M., BOCIANOWSKI, J., MARECIK, M., JANYSZEK-SOŁTYSIAK, M. 2020. Pollen morphology and variability of Sambucus nigra L. - Adoxaceae. In Biologia, vol. 75, p. 481-493. https://doi.org/10.2478/s11756-019-00396-8

XIONG, H., YUAN, D.-Y., CHEN, Y., NIU, G., ZOU, F. 2020. Pollen morphology of chestnut cultivars in southern China by using the scanning electron microscope, In Bangladesh Journal of Botany, vol. 49(1), p. 39-46. https://doi.org/10.3329/bjb.v49i1.49089 